Article

\title{
Fatty Acid Profiles of Cow's Milk and Cheese as Affected by Mountain Pasture Type and Concentrate Supplementation
}

\author{
Mirco Corazzin $\mathbb{D}^{\mathbb{D}}$, Alberto Romanzin *, Angela Sepulcri, Maurizio Pinosa, Edi Piasentier $\mathbb{D}$ and \\ Stefano Bovolenta
}

Department of Agricultural, Food, Environmental and Animal Sciences, University of Udine, 33100 Udine, Italy; mirco.corazzin@uniud.it (M.C.); angela.sepulcri@uniud.it (A.S.); maurizio.pinosa@uniud.it (M.P.); edi.piasentier@uniud.it (E.P.); stefano.bovolenta@uniud.it (S.B.)

* Correspondence: alberto.romanzin@uniud.it; Tel.: +39-0432-558191

Received: 5 November 2018; Accepted: 16 February 2019; Published: 22 February 2019

check for

Simple Summary: It is well-known that milk and cheese derived from grazing animals are beneficial for human health. Grazing dairy cows produce milk with high levels of unsaturated fatty acids and conjugated linoleic acid, which are able to reduce cardiovascular diseases and have some anticancer properties. The aim of this trial was to assess the effect of pasture type and concentrate supplementation levels on the fatty acid composition of milk and cheese obtained during summer grazing on mountain pasture. Seventy-two dairy cows, supplemented with $3.0 \mathrm{~kg} / \mathrm{head} / \mathrm{d}$ or $1.5 \mathrm{~kg} / \mathrm{head} / \mathrm{d}$ of energetic concentrate feed in the diet, grazed on a nutritionally rich Poion alpinae pasture, and subsequently a nutritionally poor Seslerion caeruleae pasture. In milk, the highest concentrate level reduced linolenic acid and total polyunsaturated fatty acids, while the pasture type influenced the monounsaturated fatty acids. In cheeses, these differences were markedly reduced.

\begin{abstract}
The aim of this trial was to assess the effect of pasture type and concentrate supplementation on the fatty acids (FA) composition of milk and cheese obtained during summer grazing on mountain pasture. Seventy-two Italian Simmental dairy cows were assigned to two groups that differed by the amount of concentrate supplementation: $3.0 \mathrm{~kg} / \mathrm{head} / \mathrm{d}$ (HIGH) vs. $1.5 \mathrm{~kg} / \mathrm{head} / \mathrm{d}$ (LOW). The dairy cows grazed on a Poion alpinae alliance pasture (PAST1), and subsequently they grazed on a Seslerion caeruleae alliance pasture (PAST2) for $10 \mathrm{~d}$ each. In the last three days of each experimental period, milk samples were collected immediately before each cheese-making event. Cheese samples were collected from each cheese loaf after $60 \mathrm{~d}$ of ripening. LOW showed higher isoFA, FA intermediates of the ruminal biohydrogenation, $\mathrm{C} 18: 3 c 9, c 12, c 15$, and total polyunsaturated fatty acid (PUFA) levels than HIGH. The pasture type had a more limited effect on FA composition of milk than concentrate level and was mainly related to monounsaturated fatty acids (MUFA), which were higher in PAST1 than PAST2 $(p<0.05)$. In cheeses, these differences were reduced. The phytanic acid and phytanic isomer ratio (SRR/RRR) in milk were not affected either by supplement level $(p>0.05)$ or by type of pasture $(p>0.05)$. Increasing the concentrate offered to dairy cows from 1.5 to $3.0 \mathrm{~kg} / \mathrm{d}$ did not markedly influence the level of PUFA in cheeses produced during summer grazing on high mountain pasture.
\end{abstract}

Keywords: dairy cow; alpine pasture; supplement; milk; cheese; fatty acid

\section{Introduction}

In Europe, from 2010 to 2013, the area of permanent grassland and meadows was reduced by $2 \%$, while the number of holdings with permanent grassland and meadows was reduced by $9 \%$ [1]. 
These reductions have been even more pronounced in less favored areas, such as high mountains, where large areas of grasslands have been abandoned [2]. Salvador et al. [3] reported that the number of meadows and pastures, and the number of farms have decreased by over $25 \%$ and $60 \%$ in the Italian Alps, respectively. In mountain areas, grasslands allow for the subsistence of dairy farms by providing much of the ruminants' feed. Mountain dairy farms are widely recognized as providing a so-called 'ecosystem service' to society [4]. Indeed, they have a role in carbon sequestration, in soil fertility, in cultural heritage maintenance, and in fire hazard prevention [5]. Moreover, especially during the summer, mountain and Alpine farms are increasingly linked to the development of tourism in the area, thanks to the unspoiled environment that they can offer to the tourist [6].

In mountain areas, dairy cows are kept indoors all year with the exception of the summer months, when the cows are allowed to graze. During the grazing season, dairy cows are usually moved through different pastures to take full advantage of the available territory following the vegetation gradient and the so-called 'vertical transhumance' animal management strategy. Moreover, the use of pasture is considered as a tool to increase the added value of summer dairy products obtained from mountain farms [7,8]. Indeed, it is well-known that dairy cows fed pasture-based diets produce milk richer in unsaturated fatty acids than cows fed total mixed ration or hay-based diets [7,9-11]. Several studies have shown that these fatty acids (FA) are favorable to human health. In particular, polyunsaturated fatty acids (PUFA) are able to decrease cardio-vascular disease risk [12] and, in animal models, conjugated linoleic acids (CLA) have been shown to be involved in anti-carcinogenic, immunomodulatory, and anti-diabetic activities [13]. Over the years, these findings have allowed dairy products to acquire a healthy image, increasing consumer interest. From this point of view, some markers, such as phytanic acid and the ratio between its two isomers-3S, 7R, 11R, 15-phytanic acid (SRR) and 3R, 7R, 11R, 15-phytanic acid (RRR)-were proposed to distinguish dairy products on the basis of the concentrate or fresh herbage offered to animals [14]. The effect of pasture on the FA composition of milk and cheese is highly variable depending on many factors, such as the amount of herbage intake, botanical and chemical composition and vegetative stage of the pasture, and concentrate feed supply in animals' diets [10,15-17]. Indeed, in recent decades, the intensification process of husbandry systems has caused an increase in the nutritional requirements of lactating cows. Fresh forage is no longer enough to ensure the nutritional requirements and welfare of the main cosmopolitan breeds of grazing cows. Lactating cows especially must receive adequate supplementation to reduce the loss of milk production and body condition. The concentrate level in the diet can influence not only the FA composition of dairy products, but also the productive performance, eating behavior, and ruminal activity of grazing cows [18,19].

This study aimed to assess the effect of pasture type and concentrate supplementation on the FA composition of milk and cheese obtained during summer grazing. These findings could be useful to enhance the summer dairy products and to reduce the abandonment of farms in mountain area.

\section{Materials and Methods}

The trial was carried out in accordance with EU Directive 2010/63/EU; it complied with the Italian legislation on animal care (DL n. 26, 4 March 2014), and adhered to the internal rules of the University of Udine.

\subsection{Experimental Design and Samples Collection}

Seventy-two Italian Simmental dairy cows grazing day and night on high mountain pasture (Malga Montasio, Italy; lat $46^{\circ} 24^{\prime} 45^{\prime \prime} \mathrm{N}$, long $13^{\circ} 25^{\prime} 53^{\prime \prime} \mathrm{E}$; $1500-1800 \mathrm{~m}$ asl) were assigned to two homogeneous experimental groups according to their productive performance recorded after a preliminary period of two weeks for milk yield $(16.9 \pm 3.3 \mathrm{~kg} / \mathrm{d})$, stage of lactation $(192.8 \pm 64.0$ days in milk (DIM)), fat (3.94 $\pm 0.25 \%)$, protein (3.29 $\pm 0.14 \%)$, lactose $(4.71 \pm 0.12 \%)$, and somatic cell count (SCC) $(130,000 \pm 47,000$ cells $/ \mathrm{mL})$. The groups differed for amount of concentrate supplementation: $3.0 \mathrm{~kg} /$ head $/ \mathrm{d}(\mathrm{HIGH})$ vs. $1.5 \mathrm{~kg} / \mathrm{head} / \mathrm{d}$ (LOW). The concentrate was mainly based on maize, barley, 
beet pulp, and soy, and its chemical composition and fatty acid profile are reported in Table 1 . The dairy cows grazed on a nutritionally rich pasture (Poion alpinae alliance pasture, $1500 \mathrm{~m}$ asl; PAST1) for $10 \mathrm{~d}$, and after another adaptation period of two weeks, they grazed on a nutritionally poor pasture (Seslerion caeruleae alliance pasture, $1700 \mathrm{~m}$ asl; PAST2) for $10 \mathrm{~d}$. PAST 1 was mainly composed of $66.5 \%$ Poaceae and Cyperaceae, $7.4 \%$ Ranunculaceae, and 2.8\% Fabaceae, while PAST2 was mainly composed of $61.8 \%$ Poaceae and Cyperaceae, 8.5\% Asteraceae, 5.4\% Fabaceae, and 3.3\% Rosaceae. Both pastures were grazed at the flowering stage of Poaceae with shepherd-guided grazing. Concentrate was offered to animals twice daily in the milking parlor. More details are reported in Bovolenta et al. [20]. For three days distributed equally over the grazing period, samples of the herbage, selected by four cows randomly chosen in each experimental group, were collected following the hand-plucking technique [21], which is manual collection of the herbage simulating animal bite size. These samples were bulked within day, and treatment and the proximate and FA analysis were carried out. The cheese-making was performed using whole raw milk, in accordance with PDO Montasio product specifications and as reported in Bovolenta et al. [20], in the three last days for each experimental period and for each experimental group, mixing evening and morning milk. A total of 12 loaves of cheese were produced. For the chemical analysis, bulked milk samples were collected immediately before each cheese-making, while cheese samples were collected from each loaf after $60 \mathrm{~d}$ of ripening and after removing $10 \mathrm{~mm}$ of rind.

Table 1. Chemical composition and fatty acid profiles of the herbage selected by cows as affected by pasture type and supplement level $(n=12)$, and of the concentrate offered.

\begin{tabular}{|c|c|c|c|c|c|c|c|c|}
\hline \multirow{3}{*}{ Items } & \multicolumn{7}{|c|}{ Herbage Selected } & \multirow{3}{*}{$\begin{array}{c}\text { Concentrate } \\
\text { Offered }\end{array}$} \\
\hline & \multicolumn{2}{|c|}{ Pasture Type } & \multicolumn{2}{|c|}{ Supplement Level } & \multirow{2}{*}{ SEM } & \multicolumn{2}{|c|}{$p$-Value } & \\
\hline & PAST1 & PAST2 & HIGH & LOW & & $\mathbf{P}$ & $\mathrm{S}$ & \\
\hline \multicolumn{9}{|c|}{ Chemical composition, g/100 g DM } \\
\hline $\mathrm{DM}$ & 26.9 & 32.2 & 29.3 & 29.8 & 0.31 & $<0.001$ & 0.402 & 87.9 \\
\hline $\mathrm{CP}$ & 12.9 & 11.2 & 12.2 & 11.9 & 0.12 & $<0.001$ & 0.173 & 14.7 \\
\hline $\mathrm{EE}$ & 2.5 & 2.8 & 2.7 & 2.7 & 0.03 & 0.001 & 0.665 & 2.7 \\
\hline $\mathrm{NDF}$ & 53.8 & 53.9 & 53.1 & 54.6 & 0.56 & 0.916 & 0.221 & - \\
\hline \multicolumn{9}{|c|}{ Fatty acid profile, $\mathrm{g} / 100 \mathrm{~g}$ of total fatty acids } \\
\hline C10:0 & 0.60 & 0.59 & 0.57 & 0.62 & 0.027 & 0.868 & 0.366 & - \\
\hline $\mathrm{C} 12: 0$ & 0.64 & 0.52 & 0.67 & 0.49 & 0.066 & 0.361 & 0.227 & - \\
\hline C14:0 & 1.56 & 1.33 & 1.67 & 1.23 & 0.216 & 0.615 & 0.333 & 0.06 \\
\hline $\mathrm{C} 16: 0$ & 18.16 & 17.38 & 18.21 & 17.33 & 0.334 & 0.274 & 0.221 & 13.70 \\
\hline C16:1 & 0.92 & 0.87 & 0.88 & 0.91 & 0.047 & 0.659 & 0.748 & - \\
\hline $\mathrm{C} 17: 0$ & 0.47 & 0.42 & 0.48 & 0.41 & 0.033 & 0.499 & 0.296 & - \\
\hline C18:0 & 3.63 & 2.93 & 3.51 & 3.05 & 0.286 & 0.252 & 0.433 & 5.99 \\
\hline $\mathrm{C} 18: 1 c 9$ & 8.12 & 8.69 & 8.26 & 8.54 & 0.428 & 0.523 & 0.753 & 21.56 \\
\hline $\mathrm{C} 18: 2 c 9, c 12$ & 19.77 & 21.76 & 20.68 & 20.85 & 0.465 & 0.061 & 0.860 & 55.42 \\
\hline $\mathrm{C} 18: 3 c 6, c 9, c 12$ & 0.88 & 0.98 & 0.90 & 0.95 & 0.055 & 0.405 & 0.681 & - \\
\hline $\mathrm{C} 18: 3 c 9, c 12, c 15$ & 44.06 & 42.65 & 42.77 & 43.93 & 1.030 & 0.509 & 0.587 & 3.27 \\
\hline $\mathrm{C} 20: 3 c 11, c 14, c 17$ & 0.54 & 0.69 & 0.62 & 0.61 & 0.052 & 0.183 & 0.899 & - \\
\hline C20:4 c5,c8,c11,c14 & 0.66 & 1.20 & 0.77 & 1.08 & 0.089 & 0.014 & 0.113 & - \\
\hline
\end{tabular}

SEM: standard error of the mean; P: pasture type; S: supplement level; DM: dry matter; CP: crude protein; EE: ether extract; NDF: neutral detergent fiber; $c$ : cis.

\subsection{Chemical Analyses}

The herbage and concentrate samples were dried in a forced draft oven at $65{ }^{\circ} \mathrm{C}$ for $48 \mathrm{~h}$ and analyzed for crude protein $(\mathrm{CP})$ and ether extract (EE) according to Association of Official Agricultural Chemists (AOAC) [22], and for neutral detergent fiber (NDF) according to Goering and Van Soest [23].

On milk samples, the following determinations were carried out: fat, protein, lactose [24], urea [22], and somatic cell count (SCC; Foss-o-Matic, Foss Electric, Hillerod, Denmark). SCC data was analyzed as: somatic cell score $(\mathrm{SCS})=\log _{2}(\mathrm{SCC} / 100,000)+3$ [25]

The cheese samples were analyzed for fat and protein according to AOAC [22]. 
Fatty acids of herbage and concentrate samples were determined as methyl esters, extracted by chloroform:methanol $(2: 1, v / v)$ [26], and esterified using methanolic hydrogen chloride [27]. Fatty acid methyl esters were separated in a gas chromatograph (HRGC 5300, Carlo Erba, Cornaredo, Italy) with split injection (ratio 1:50), flame ionization detector (FID), and ChemStation software (Hewlett Packard 3365, Avondale, PA, USA) for chromatogram integration. The capillary column was an SP 2380 capillary column $(60 \mathrm{~m} \times 0.25 \mu \mathrm{m} \times 0.25 \mathrm{~mm}$; Supelco, Oakville, ON, USA), with a temperature program from 160 to $260^{\circ} \mathrm{C}$. Injector temperature was set at $250{ }^{\circ} \mathrm{C}$ and the detector was set at $260{ }^{\circ} \mathrm{C}$.

Fat was extracted from milk following the method described by Povolo et al. [28] in order to obtain the fat without using solvents. Fat extraction from cheese, conversely, was performed according to the modified Folch's technique [29].

Either way, the lipids were then esterificated in accordance with the method described by Bannon et al. [30], with modifications reported by Prandini et al. [31].

Fatty acid methyl esters were detected using a GCMS Saturn 2100T (Agilent Technologies, Italy S.p.a., Cernusco sul Naviglio, Italy) equipped with an HP-88 (Agilent Technologies, Santa Clara, CA, USA) capillary column (100 m length, $0.25 \mathrm{~mm}$ i.d, $0.20 \mu \mathrm{m}$ film thickness). Split injection $(1 \mu \mathrm{L})$ was adopted (ratio 1:50) and helium was used as a carrier gas at a flow rate of $1.2 \mathrm{~mL} / \mathrm{min}$. Oven temperature was held at $50^{\circ} \mathrm{C}$ for $5 \mathrm{~min}$, programmed to $160{ }^{\circ} \mathrm{C}$ at a rate of $10^{\circ} \mathrm{C} / \mathrm{min}$, held at $160^{\circ} \mathrm{C}$ for $10 \mathrm{~min}$, programmed to $180^{\circ} \mathrm{C}$ at $0.3^{\circ} \mathrm{C} / \mathrm{min}$, held to $180^{\circ} \mathrm{C}$ for $5 \mathrm{~min}$, and then increased to $240{ }^{\circ} \mathrm{C}$ at $20^{\circ} \mathrm{C} / \mathrm{min}$, and held at $240{ }^{\circ} \mathrm{C}$ for $10 \mathrm{~min}$. The transfer line was held at $240{ }^{\circ} \mathrm{C}$ and the mass spectroscopy source at $200^{\circ} \mathrm{C}$. Acquisition was performed in electron ionization mode $(70 \mathrm{eV})$ at $0.4 \mathrm{scan} / \mathrm{s}$, and the mass range used was $10-400 \mathrm{~m} / \mathrm{z}$. The identification of the compound was made by using the NIST library (National Institute of Standards and Technology—NIST, Gaithersburg, MD, USA), the MS data of literature, and when available, the injection of authentic standards. Fatty acid composition was expressed as $\mathrm{g} / 100 \mathrm{~g}$ of total fatty acids of milk and cheese, respectively.

\subsection{Statistical Analysis}

Data were analyzed using R software [32]. The effect of pasture type (PAST1 vs. PAST2) and concentrate level (HIGH vs. LOW) on herbage chemical characteristics was analyzed by a general linear model that considered pasture type and concentrate level as fixed effects. The milk and cheese chemical composition was subjected to a hierarchical model as reported by Bovolenta et al. [20] with pasture type and supplement level considered as fixed factors and the cheese-making day nested within the pasture treated as a random factor.

\section{Results and Discussion}

Chemical composition and fatty acid (FA) profiles of the herbage selected by cows and of the concentrate offered are reported in Table 1.

The supplement level did not influence the chemical composition or the FA profile of the herbage selected by the animals $(p>0.05)$. PAST1 showed higher CP $(p<0.01)$ and lower dry matter (DM, $p<0.01)$, ash $(p<0.05)$, and EE $(p<0.01)$ concentrations than PAST2. The differences between the FA profiles were limited to $\mathrm{C} 20: 4 \mathrm{c5}, \mathrm{c} 8, \mathrm{c} 11, \mathrm{c} 14$, the highest in PAST2 $(p<0.05)$. Considering that the two experimental pastures were grazed at the same phenological stage, these differences may be due to their different botanical composition, as explained by Bovolenta et al. [33].

The pasture type and the supplement level did not influence $(p>0.05)$ the chemical composition of milk in terms of fat $(3.99 \pm 0.043 \%)$, protein $(3.28 \pm 0.008 \%)$, and SCS $(4.03 \pm 0.166$ units), and of cheese in terms of DM $(66.6 \pm 0.206 \%)$, fat $(53.2 \pm 0.364 \% \mathrm{DM})$, protein $(40.5 \pm 0.404 \% \mathrm{DM})$. The milk composition was similar to that reported by Romanzin et al. [18], who considered milk from Italian Simmental dairy cows grazing on mountain pasture, and by Coppa et al. [34] who considered milk from Piemontese and Simmental breeds. The urea in milk was higher in PAST2 than in PAST1 (23.3 vs. $20.3, p<0.01)$ and higher in LOW than in HIGH groups (22.9 vs. $20.7, p<0.01)$, although its average value was within the range of normality of $15-30 \mathrm{mg} / \mathrm{dL}$ proposed by Bendelja et al. [35]. The average 
SCS observed corresponded to a value of about 204,000 cells $/ \mathrm{mL}$ which was slightly higher that the threshold, 200,000 cells/mL, proposed for detecting animals with healthy mammary glands [36,37]. However, it was lower than the value of 308,000 cells $/ \mathrm{mL}$ reviewed by Corazzin et al. [38] and recorded in a wide survey involving a mountain dairy farm. The cheese composition was similar to that reported by Romanzin et al. [7] and Bovolenta et al. [39] in cheeses produced with a very similar production process.

The FA composition of experimental milk is shown in Table 2.

Table 2. Fatty acid composition (g/100 g of total fatty acids) of milk as affected by pasture type and supplement level; $n=12^{1}$.

\begin{tabular}{|c|c|c|c|c|c|c|c|}
\hline \multirow{2}{*}{ Fatty Acid } & \multicolumn{2}{|c|}{ Pasture Type } & \multicolumn{2}{|c|}{ Supplement Level } & \multirow{2}{*}{ SEM } & \multicolumn{2}{|c|}{$p$-Value } \\
\hline & PAST1 & PAST2 & HIGH & LOW & & $\mathbf{P}$ & $\mathrm{S}$ \\
\hline C4:0 & 4.66 & 4.54 & 4.62 & 4.58 & 0.036 & 0.148 & 0.531 \\
\hline C6:0 & 2.71 & 2.64 & 2.69 & 2.66 & 0.025 & 0.174 & 0.519 \\
\hline C8:0 & 1.46 & 1.42 & 1.45 & 1.43 & 0.014 & 0.183 & 0.541 \\
\hline C10:0 & 2.83 & 2.78 & 2.81 & 2.80 & 0.013 & 0.101 & 0.669 \\
\hline C10:1 & 0.22 & 0.19 & 0.20 & 0.21 & 0.003 & $<0.001$ & 0.798 \\
\hline C12:0 & 2.97 & 2.93 & 2.95 & 2.96 & 0.006 & 0.013 & 0.588 \\
\hline C13:0 & 0.16 & 0.14 & 0.16 & 0.14 & 0.008 & 0.343 & 0.343 \\
\hline iso-C14:0 & 0.20 & 0.23 & 0.20 & 0.23 & 0.003 & 0.002 & 0.002 \\
\hline C14:0 & 10.00 & 9.95 & 9.93 & 10.02 & 0.018 & 0.137 & 0.048 \\
\hline iso-C15:0 & 0.40 & 0.47 & 0.41 & 0.46 & 0.004 & $<0.001$ & $<0.001$ \\
\hline anteiso-C15:0 & 0.88 & 0.98 & 0.91 & 0.96 & 0.016 & 0.010 & 0.158 \\
\hline $\mathrm{C} 14: 1 c 9$ & 0.69 & 0.63 & 0.66 & 0.66 & 0.022 & 0.178 & 0.940 \\
\hline C15:0 & 1.39 & 1.45 & 1.37 & 1.48 & 0.014 & 0.064 & 0.003 \\
\hline iso-C16:0 & 0.41 & 0.49 & 0.43 & 0.47 & 0.005 & $<0.001$ & 0.007 \\
\hline C16:0 & 24.97 & 24.75 & 24.79 & 24.93 & 0.024 & 0.001 & 0.021 \\
\hline C16:1 c7 & 0.23 & 0.24 & 0.22 & 0.24 & 0.005 & 0.307 & 0.058 \\
\hline iso-C17:0 & 0.55 & 0.56 & 0.55 & 0.56 & 0.003 & 0.624 & 0.163 \\
\hline $\mathrm{C} 16: 1 c 9$ & 1.38 & 1.48 & 1.40 & 1.46 & 0.033 & 0.192 & 0.414 \\
\hline anteiso-C17:0 & 0.72 & 0.80 & 0.73 & 0.80 & 0.007 & $<0.001$ & 0.001 \\
\hline Phytanic & 0.31 & 0.33 & 0.30 & 0.34 & 0.009 & 0.206 & 0.061 \\
\hline C17:0 & 0.87 & 1.09 & 0.95 & 1.01 & 0.015 & $<0.001$ & 0.057 \\
\hline iso-C18:0 & 0.08 & 0.10 & 0.09 & 0.10 & 0.003 & 0.003 & 0.081 \\
\hline C17:1 & 0.24 & 0.24 & 0.25 & 0.26 & 0.001 & 0.161 & $<0.001$ \\
\hline C18:0 & 10.89 & 10.82 & 11.05 & 10.66 & 0.017 & 0.076 & $<0.001$ \\
\hline C18:1 t6-8-9-10 & 0.34 & 0.29 & 0.43 & 0.21 & 0.055 & 0.630 & 0.079 \\
\hline C18:1 t11 & 3.03 & 3.01 & 2.97 & 3.07 & 0.005 & 0.086 & $<0.001$ \\
\hline $\mathrm{C} 18: 1 c 9$ & 19.38 & 19.26 & 19.76 & 18.88 & 0.030 & 0.075 & $<0.001$ \\
\hline C18:1 t15 & 0.22 & 0.15 & 0.17 & 0.20 & 0.017 & 0.104 & 0.360 \\
\hline C18:1 c11 & 0.50 & 0.59 & 0.67 & 0.42 & 0.034 & 0.106 & 0.007 \\
\hline C18:1 c12 & 0.20 & 0.25 & 0.25 & 0.20 & 0.005 & 0.001 & 0.002 \\
\hline$C 18: 1 c 14+t 16$ & 0.55 & 0.19 & 0.37 & 0.37 & 0.041 & 0.002 & 0.945 \\
\hline$C 18: 1 t 12+t 13+t 14$ & 0.04 & 0.13 & 0.05 & 0.12 & 0.016 & 0.025 & 0.074 \\
\hline C18:2 t11,c15 & 0.81 & 0.79 & 0.68 & 0.92 & 0.028 & 0.792 & 0.002 \\
\hline $\mathrm{C} 18: 2 c 9, c 12$ & 2.00 & 2.02 & 1.90 & 2.13 & 0.063 & 0.948 & 0.104 \\
\hline C20:0 & 0.23 & 0.35 & 0.26 & 0.31 & 0.011 & $<0.001$ & 0.048 \\
\hline $\mathrm{C} 18: 3 c 9, c 12, c 15$ & 1.09 & 1.08 & 1.03 & 1.15 & 0.002 & 0.096 & $<0.001$ \\
\hline $\mathrm{C} 18: 2 c 9, t 11$ & 1.36 & 1.35 & 1.35 & 1.36 & 0.002 & 0.082 & 0.039 \\
\hline C18:2 CLA ${ }^{2}$ & 0.46 & 0.64 & 0.44 & 0.66 & 0.042 & 0.059 & 0.029 \\
\hline C20:4 c5,c8,c11,c14 & 0.07 & 0.08 & 0.05 & 0.10 & 0.003 & 0.133 & $<0.001$ \\
\hline Phytanic SRR/RRR ${ }^{3}$ & 0.428 & 0.433 & 0.401 & 0.460 & 0.019 & 0.893 & 0.158 \\
\hline SFA & 66.86 & 66.98 & 66.82 & 67.02 & 0.073 & 0.433 & 0.219 \\
\hline MUFA & 27.13 & 26.79 & 27.51 & 26.41 & 0.041 & 0.003 & $<0.001$ \\
\hline PUFA & 6.02 & 6.23 & 5.67 & 6.58 & 0.052 & 0.066 & $<0.001$ \\
\hline
\end{tabular}

SEM: standard error of the mean; P: pasture type; S: supplement level; CLA: conjugated linoleic acid; SFA: saturated FA; MUFA: monounsaturated FA; PUFA: polyunsaturated FA; $c$ : cis; $t$ : trans. ${ }^{1}$ Fatty acids detected at $<0.1 \%$ of total lipids are not reported; ${ }^{2}$ This peak can include $t 7, c 9$ and $t 8, c 10$ according to Collomb et al. [40] and Kramer et al. [41], C18:2 $c 9, t 11$ is excluded; ${ }^{3}$ Ratio between diastereomers of phytanic, 3S,7R,11R,15 and 3R,7R,11R,15.

Considering the saturated FA of milk, the concentrations of C14:0 $(p<0.05)$, iso-C14:0 $(p<0.01)$, iso-C15:0 ( $p<0.01), \mathrm{C} 15: 0(p<0.01)$, iso-C16:0 $(p<0.01)$, ante-iso-C17:0 $(p<0.01), \mathrm{C} 16: 0(p<0.05), \mathrm{C} 20: 0$ 
$(p<0.05)$ were higher in LOW than HIGH milk; instead, the C18:0 $(p<0.01)$ level was highest in milk from the HIGH group. Moreover, LOW tended to have higher C17:0 $(p<0.10)$, and iso-C18:0 $(p<0.10)$ than the HIGH group. Vlaeminck et al. [42] explained that iso-C14:0, iso-C15:0, C15:0, iso-C16:0 are constituents of the bacterial membrane, and that their variation can reflect variations in the bacterial ruminal population. Indeed, the same authors found that cellulolytic bacteria membranes are particularly rich in iso-FA. Therefore, we supposed that the animals from the experimental groups had different ruminal bacterial populations, with the LOW having higher cellulolytic ruminal bacteria than the HIGH group. This hypothesis reflects the probable highest forage/concentrate ratio of the diet of the LOW group. We had to take into account that linear odd-chain FA, and ante-iso-FA can also derive from mammary gland de-novo synthesis, and that the $\mathrm{C} 17: 1 / \mathrm{C} 17: 0$ is also regulated by the action of the $\Delta 9$ desaturase enzyme [42]. Although Kilcawley et al. [43] argued that higher herbage intake can inhibit de-novo FA synthesis, the effect of concentrate on mammary gland enzyme activity or expression seems to be limited. Indeed, the level of short chain FAs, that are indicators of FA synthesis [44], were similar between experimental groups $(p>0.10)$ with the only exception being C14:0, which was highest in the LOW group $(p<0.05)$. Additionally, the C17:1/C17:0 ratio was similar between experimental groups $(0.245 \pm 0.011 ; p>0.05)$, reinforcing the hypothesis that the differences observed for the saturated FA previously reported were due to a different selection of ruminal bacterial populations.

Considering the unsaturated FA of milk, the concentrations of C17:1 $(p<0.01), \mathrm{C} 18: 1$ t11 $(p<0.01)$, CLA $(p<0.05)$, C18:2 t11,c15 ( $p<0.01)$, C18:3 $c 9, c 12, c 15(p<0.01)$, and C20:4 $c 5, c 8, c 11, c 14(p<0.01)$ were higher in LOW than HIGH milk; instead, the C18:1 $c 9(p<0.01), \mathrm{C} 18: 1 c 11(p<0.01)$, and C18:1 $c 12(p<0.01)$ levels were highest in milk from the HIGH group. Moreover, LOW milk tended to have higher $\mathrm{C} 16: 1 c 7(p<0.10)$ and the sum of $\mathrm{C} 18$ : $t 12 / t 13 / t 14$ isomers $(p<0.10)$, and lower C18:1 t6-8-9-10 $(p<0.10)$ than the HIGH group. It is accepted that $\mathrm{C} 18: 3 c 9, c 12, c 15$ and $\mathrm{C} 18: 2 c 9, c 12$ originated in the feed. The herbage ingested contained more than $40 \%$ of the total FA of $\mathrm{C} 18: 3 c 9, c 12, c 15$; in particular, the level of this FA was $1.17 \mathrm{~g} / 100 \mathrm{~g}$ DM and $0.09 \mathrm{~g} / 100 \mathrm{~g}$ DM in herbage and concentrate, respectively. Therefore, it is reasonable that the LOW group, fed with a lower level of concentrate, ingested a higher amount of herbage, explaining the differences observed in the concentration of $\mathrm{C} 18: 3 c 9, c 12, c 15$. Conversely, it seems that the differences of $\mathrm{C} 18: 2 c 9, \mathrm{c} 12$ in the two diets were not enough to generate variations in this FA in the milk of the experimental groups. Indeed, the level of $C 18: 2 c 9, c 12$ was $0.56 \mathrm{~g} / 100 \mathrm{~g}$ DM and $1.50 \mathrm{~g} / 100 \mathrm{~g}$ DM in herbage and concentrate, respectively. C18:1 $t 11$ and C18:2 $t 11, c 15$ are intermediates of the ruminal biohydrogenation of the dietary unsaturated FA, and, therefore, it can be speculated that the ruminal biohydrogenation was higher in animals receiving a lower level of concentrate in accordance with Khanal et al. [45] and Bovolenta et al. [46]. Additionally, Rego et al. [47] showed that increasing the fresh herbage intake by animals, also led to increased levels of C18:1 t11, CLA, and C18:3 $c 9, c 12, c 15$. It is interesting to note that the C18:0 level, a final product of the ruminal biohydrogenation of dietary FA, was higher in the HIGH than LOW group. Taking into account our results, it could be hypothesized that the final step of rumen biohydrogenation was inhibited in the LOW group. Dewanckele et al. [48] explained that diets rich in PUFA can inhibit the last step of rumen biohydrogenation by modifying the rumen bacteria population, resulting in increased intermediate products, as observed also in the present paper. Since $\mathrm{C} 18: 1 c 9$ can derive from the desaturation of $\mathrm{C} 18: 0$, the difference observed in this FA could be due to the different levels of $\mathrm{C} 18: 0$ between experimental groups.

Considering the groups of FA, the level of PUFA $(p<0.01)$ was higher, while the level of MUFA was lower $(p<0.01)$ in LOW than HIGH group. Romanzin et al. [7], comparing the FA profile of milk from dairy cows grazing on mountain pasture or fed a hay-based diet, showed that the herbage intake increased the level both of PUFA and MUFA. However, in agreement with the present study, Marín et al. [49] showed that by reducing concentrate supplementation to grazing cows from $6-8 \mathrm{~kg} / \mathrm{d}$ to $1-2 \mathrm{~kg} / \mathrm{d}$, the level of milk MUFA decreased.

The pasture type had a more limited effect on FA composition of milk than concentrate levels in animals' diets. Indeed, PAST1 showed higher levels of C10:1 $(p<0.01), \mathrm{C} 12: 0(p<0.05), \mathrm{C} 16: 0(p<0.01)$, 
C18:1 $c 14 / t 16(p<0.01)$, and MUFA $(p<0.01)$, but lower levels of iso-C14:0 $(p<0.01)$, iso-C15:0 $(p<0.01)$, ante-iso-C15:0 $(p<0.05)$, iso-C16:0 ( $p<0.01)$, ante-iso-C17:0 $(p<0.01), \mathrm{C} 17: 0(p<0.01)$, iso-C18:0 $(p<0.01)$, C18:1 $c 12(p<0.01), C 18: 1 t(p<0.05)$, and C20:0 $(p<0.01)$ than the PAST2 group. Despite not being measured, the difference in the herbage intake by animals between PAST1 and PAST2 can be considered very small following the INRA standard [50]. As for the different level of concentrate supplementation and taking into account the results about iso-FA, ante-iso-C15:0, and ante-iso-C17:0, we can speculate that the different pasture type was able to influence the ruminal bacteria population. Conversely, in the present study, since only C12:0 of the short chain FAs was different between pastures, the effect of pasture type on mammary de novo synthesis of FA was not evident. Similarly, taking into account that only C18:1 $t$ and C18:1 c12 were different between experimental groups, the effect of pasture type on ruminal biohydrogenation of dietary FA was also not evident. In the literature, the effect of pasture type on milk FA is highly variable. Khiosa-Ard et al. [51] found that the level of C18:3 $c 9, c 12, c 15$ in milk was influenced by the botanical family of plants ingested by animals, which is not in agreement with the results of the present study. Falchero et al. [52], comparing two alpine pastures, showed differences only in the level of C15:0 and C16:0 of milk. Gorlier et al. [53] found that the pasture type was not able to influence the FA profile of milk; at the same time, they showed that the presence of the botanical family of Poaceae was correlated positively with MUFA and negatively with C18:2 c9,c12 levels in milk. Conversely, Collomb et al. [54], with regard to Poaceae, reported a significant positive correlation with SFA, a negative significant correlation with PUFA, and no correlation with MUFA. The Alpine pastures are characterized by a high botanical diversity, and different plants can contain different levels of secondary metabolites, such as polyphenol oxidase and tannins, that can influence the metabolism of FA [55]. Therefore, not only the plant family, but also the single plant species of the pasture can influence the FA composition [54,56].

Phytanic acid and its isomers' SRR/RRR ratio in milk was not affected either by supplement level $(p>0.05)$ or type of pasture $(p>0.05)$. Only the LOW group tended to have higher phytanic acid content than the HIGH group $(p<0.10)$. Phytanic acid cannot be synthetized by dairy cows and has a dietary origin deriving from the metabolism of chlorophyll in the rumen, while the SRR/RRR diastereomer ratio depends on the microbial flora present in the rumen as a consequence of the animal's diet [14,57]. Therefore, phytanic acid, and its SRR/RRR diastereomer ratio were proposed as markers for authentication of organic milk, and consequently, to assess the fresh herbage feeding of dairy cows [14]. However, Che et al. [58] observed a significant and high correlation between the SRR/RRR ratio and intake of grazed clovers, but these authors failed to find a correlation between the SRR/RRR ratio and intake of grazed grass by cows. In the present trial, the different amounts of concentrate offered between experimental groups was probably too low to provide differences in the phytanic acid level and SRR/RRR ratio in milk. This statement seems to be supported by the fact that Vetter and Schröder [57] indicated a threshold of $0.20 \%$ of phytanic acid for distinguishing organic from conventional dairy products, and in the present trial, all the experimental milk showed a phytanic acid level higher than $0.25 \%$.

Many studies have reported that SFA, and C12:0, C14:0, and C16:0 in particular, have hypercholesterolemic properties and favor the increase of blood low density lipoprotein $[59,60]$. Conversely, PUFA, and $C 18: 3 c 9, c 12, c 15$ in particular, have beneficial effects for human health, such as reduction of plasma triacylglycerol and plasma pressure [59]. In the present trial, the LOW group showed levels of PUFA and $C 18: 3 c 9, c 12, c 15$ that were $15 \%$ and $12 \%$ higher, respectively, than those shown by the HIGH group. Moreover, the milk produced from cows grazing on Seslerion caeruleae alliance pasture (PAST2 group) showed a level of C12:0 and C16:0 around 1\% lower than those produced from cows grazing on Poion alpinae alliance pasture (PAST1 group). Therefore, LOW and PAST2 had a more beneficial FA profile of milk than HIGH and PAST1 groups, respectively.

The FA composition of experimental cheeses is showed in Table 3. 
Table 3. Fatty acid composition (g/100 g of total fatty acids) of cheese as affected by pasture type and supplement level; $n=12^{1}$.

\begin{tabular}{|c|c|c|c|c|c|c|c|}
\hline \multirow{2}{*}{ Fatty Acid } & \multicolumn{2}{|c|}{ Pasture Type } & \multicolumn{2}{|c|}{ Supplement Level } & \multirow{2}{*}{ SEM } & \multicolumn{2}{|c|}{$p$-Value } \\
\hline & PAST1 & PAST2 & HIGH & LOW & & $\mathbf{P}$ & $\mathrm{S}$ \\
\hline C4:0 & 4.61 & 4.60 & 4.65 & 4.56 & 0.013 & 0.737 & 0.007 \\
\hline C6:0 & 3.26 & 2.68 & 3.34 & 2.61 & 0.282 & 0.330 & 0.229 \\
\hline $\mathrm{C} 8: 0$ & 1.46 & 1.45 & 1.52 & 1.39 & 0.004 & 0.775 & $<0.001$ \\
\hline C10:0 & 2.93 & 2.93 & 3.06 & 2.81 & 0.009 & 0.775 & $<0.001$ \\
\hline C10:1 & 0.21 & 0.17 & 0.18 & 0.20 & 0.008 & 0.043 & 0.185 \\
\hline C12:0 & 3.13 & 3.12 & 3.23 & 3.02 & 0.009 & 0.766 & $<0.001$ \\
\hline C13:0 & 0.17 & 0.16 & 0.17 & 0.16 & 0.001 & 0.755 & $<0.001$ \\
\hline iso-C14:0 & 0.19 & 0.22 & 0.20 & 0.21 & 0.002 & $<0.001$ & 0.144 \\
\hline C14:0 & 10.50 & 10.47 & 10.55 & 10.42 & 0.031 & 0.732 & 0.074 \\
\hline iso-C15:0 & 0.38 & 0.45 & 0.41 & 0.42 & 0.004 & $<0.001$ & 0.049 \\
\hline anteiso-C15:0 & 0.77 & 0.88 & 0.82 & 0.83 & 0.012 & 0.002 & 0.867 \\
\hline $\mathrm{C} 14: 1 c 9$ & 0.75 & 0.70 & 0.72 & 0.73 & 0.012 & 0.050 & 0.712 \\
\hline C15:0 & 1.34 & 1.41 & 1.36 & 1.38 & 0.012 & 0.020 & 0.555 \\
\hline iso-C16:0 & 0.38 & 0.44 & 0.42 & 0.40 & 0.008 & 0.007 & 0.332 \\
\hline C16:0 & 24.86 & 24.81 & 24.88 & 24.78 & 0.072 & 0.728 & 0.515 \\
\hline $\mathrm{C} 16: 1 c 7$ & 0.19 & 0.20 & 0.19 & 0.20 & 0.007 & 0.712 & 0.332 \\
\hline iso-C17:0 & 0.58 & 0.58 & 0.57 & 0.59 & 0.002 & 0.699 & $<0.001$ \\
\hline $\mathrm{C} 16: 1 c 9$ & 1.34 & 1.37 & 1.34 & 1.37 & 0.022 & 0.528 & 0.505 \\
\hline anteiso-C17:0 & 0.68 & 0.56 & 0.52 & 0.72 & 0.058 & 0.300 & 0.135 \\
\hline Phytanic & 0.40 & 0.38 & 0.36 & 0.42 & 0.019 & 0.609 & 0.158 \\
\hline C17:0 & 0.85 & 0.99 & 0.93 & 0.91 & 0.011 & $<0.001$ & 0.488 \\
\hline iso-C18:0 & 0.10 & 0.09 & 0.10 & 0.09 & 0.004 & 0.790 & 0.593 \\
\hline C17:1 & 0.25 & 0.25 & 0.24 & 0.25 & 0.001 & 0.696 & $<0.001$ \\
\hline C18:0 & 10.44 & 10.42 & 9.94 & 10.92 & 0.030 & 0.670 & $<0.001$ \\
\hline C18:1 t6-8-9-10 & 0.43 & 0.48 & 0.46 & 0.46 & 0.025 & 0.352 & 0.904 \\
\hline $\mathrm{C} 18: 1 t 11$ & 2.99 & 2.98 & 2.94 & 3.03 & 0.009 & 0.708 & 0.001 \\
\hline $\mathrm{C} 18: 1 c 9$ & 19.47 & 19.43 & 19.14 & 19.76 & 0.056 & 0.707 & $<0.001$ \\
\hline $\mathrm{C} 18: 1 t 15$ & 0.16 & 0.05 & 0.05 & 0.15 & 0.021 & 0.041 & 0.044 \\
\hline C18:1 c11 & 0.54 & 0.49 & 0.59 & 0.44 & 0.087 & 0.801 & 0.431 \\
\hline $\mathrm{C} 18: 1$ c12 & 0.11 & 0.37 & 0.36 & 0.12 & 0.046 & 0.021 & 0.025 \\
\hline C18:1 c13 & 0.22 & 0.16 & 0.14 & 0.23 & 0.045 & 0.527 & 0.338 \\
\hline $\mathrm{C} 18: 1 c 14+t 16$ & 0.21 & 0.10 & 0.21 & 0.09 & 0.061 & 0.414 & 0.354 \\
\hline $\mathrm{C} 18: 1 t 12+t 13+t 14$ & 0.27 & 0.36 & 0.37 & 0.26 & 0.085 & 0.589 & 0.546 \\
\hline $\mathrm{C} 18: 2 t 11, c 15$ & 0.69 & 0.74 & 0.70 & 0.73 & 0.020 & 0.242 & 0.377 \\
\hline $\mathrm{C} 18: 2 c 9, c 12$ & 2.06 & 2.04 & 2.06 & 2.06 & 0.025 & 0.788 & 0.978 \\
\hline C20:0 & 0.10 & 0.21 & 0.20 & 0.11 & 0.014 & 0.004 & 0.009 \\
\hline $\mathrm{C} 18: 3 c 9, c 12, c 15$ & 0.98 & 0.98 & 0.95 & 1.00 & 0.003 & 0.696 & $<0.001$ \\
\hline $\mathrm{C} 18: 2 c 9, t 11$ & 1.34 & 1.34 & 1.34 & 1.34 & 0.004 & 0.724 & 0.655 \\
\hline C18:2 CLA $^{2}$ & 0.25 & 0.49 & 0.38 & 0.36 & 0.038 & 0.012 & 0.758 \\
\hline Phytanic SRR/RRR ${ }^{3}$ & 0.789 & 0.626 & 0.611 & 0.804 & 0.062 & 0.221 & 0.152 \\
\hline SFA & 67.24 & 66.98 & 67.35 & 66.86 & 0.178 & 0.486 & 0.203 \\
\hline MUFA & 27.18 & 27.17 & 26.99 & 27.36 & 0.141 & 0.954 & 0.222 \\
\hline PUFA & 5.58 & 5.86 & 5.66 & 5.78 & 0.056 & 0.037 & 0.334 \\
\hline
\end{tabular}

SEM: standard error of the mean; P: pasture type; S: supplement level; CLA: conjugated linoleic acid; SFA: saturated FA; MUFA: monounsaturated FA; PUFA: polyunsaturated FA; $c$ : cis; $t$ : trans. ${ }^{1}$ Fatty acids detected at $<0.1 \%$ of total lipids are not reported; ${ }^{2}$ This peak can include $t 7, c 9$ and $t 8, c 10$ according to Collomb et al. [40] and Kramer et al. [41], $\mathrm{C} 18: 2 c 9, t 11$ is excluded; ${ }^{3}$ Ratio between diastereomers of phytanic, 3S,7R,11R,15 and 3R,7R,11R,15.

The concentrations of iso-C15:0 ( $p<0.05)$, iso-C17:0 $(p<0.01), \mathrm{C} 17: 1(p<0.01), \mathrm{C} 18: 0(p<0.01)$, $\mathrm{C} 18: 1 t 11(p<0.01), \mathrm{C} 18: 1 c 9(p<0.01), \mathrm{C} 18: 1 t 15(p<0.05)$, and $\mathrm{C} 18: 3 c 9, \mathrm{c} 12, c 15(p<0.01)$ were higher in LOW than HIGH cheese; instead, the C4:0 ( $p<0.01)$, C8:0 $(p<0.01)$, C10:0 $(p<0.01)$, C12:0 $(p<0.01), \mathrm{C} 13: 0(p<0.01), \mathrm{C} 18: 1 \mathrm{c} 12(p<0.05)$, and C20:0 $(p<0.01)$ levels were highest in cheese from the HIGH group. Coppa et al. [61] observed that in cheeses ripened 12 weeks, the effect of the cheese-making process had a very small effect on the FA profile. Conversely, in the present paper, despite the differences in iso-C15:0, C17:1, C18:1 $t 11$, and C18:3 $c 9, c 12, c 15$ reflected in those of milk, some differences in FA composition in milk and cheese were found. These differences could be due to the lipolysis process that cheese underwent during ripening. From this point of view, one of the most important lipolytic agents is the lipoprotein lipase (LPL) derived from the milk and that 
is inactivated after pasteurization. This enzyme preferentially acts towards short chain fatty acids, C4-C12 [62,63]. The results of the present paper could be explained if we suppose that the different herbage intake could have influenced the LPL expression and/or activity, as previously reported in cattle by Palin et al. [64] and Corazzin et al. [65]. Unlike the results related to supplement levels, as expected the differences between cheese FA composition due to pasture type mainly reflected those observed in milk. Indeed, the cheese produced from the PAST1 group had higher C10:1 $(p<0.01)$, and C18:1 $t 15(p<0.01)$, but lower iso-C14:0 $(p<0.01)$, iso-C15:0 $(p<0.01)$, ante-iso-C15:0 $(p<0.05)$, iso-C16:0 $(p<0.01), \mathrm{C} 15: 0(p<0.01)$, iso-C16:0 ( $p<0.01), \mathrm{C} 17: 0(p<0.01), \mathrm{C} 18: 1 c 12(p<0.01), \mathrm{C} 18: 2$ CLA $(p<0.05)$, and C20:0 $(p<0.01)$ levels than those from the PAST2 group.

Considering the categories of FA, it is interesting to note that the cheese-making process and the ripening period reduced the differences between experimental groups, especially considering the supplement level factor. Indeed, the cheese of the HIGH group showed similar SFA, MUFA, and PUFA levels to those of the LOW group. Additionally, the total concentration of these categories of FA was similar between cheese and milk independent of the experimental factor. The average total amounts of SFA, MUFA, and PUFA were 66.9, 27, and 6.1\% respectively, which were similar to those reported by Romanzin et al. [7] in the same type of product, Montasio PDO cheese, which were 64.1, 32.2, and $3.7 \%$ respectively.

As for milk, phytanic acid level and its SRR/RRR diastereomer ratio were similar between experimental groups $(p>0.05)$.

\section{Conclusions}

From the milk FA profile point of view, increasing the concentrate offered to cows decreased the level of FA beneficial for human health, such as PUFA and C18:3 $c 9, c 12, c 15$, as well as some FA intermediates of rumen biohydrogenation. Conversely, the effect of the two pasture types considered was more limited.

The differences in PUFA levels in all the experimental cheeses, probably because of the cheese-making process and the ripening period, were reduced. Finally, we can conclude that the increase in the concentrate offered to dairy cows from 1.5 to $3.0 \mathrm{~kg} / \mathrm{d}$, which can have a nutritional role, does not markedly influence the level of SFA, MUFA, and PUFA in cheeses produced during summer grazing on different high mountain pastures.

Author Contributions: Conceptualization and methodology, M.C., M.P., A.R., E.P. and S.B.; Data curation and analysis, M.C. and A.R.; Laboratory analysis, A.S.; Funding acquisition, S.B.; All authors have been involved in developing, writing, and commenting on the manuscript. All authors read and approved the final manuscript.

Funding: This research was funded by Friuli Venezia Giulia Region (L.R. n. 26/2005, art. 18).

Acknowledgments: The authors are grateful to the Breeders Association of Friuli Venezia Giulia Region (AAFVG) for the technical support.

Conflicts of Interest: The authors declare no conflict of interest. The funding sponsor had no role in the design of this study; in the collection, analyses, or interpretation of data; in the writing of the manuscript, or in the final decision to publish the results.

\section{References}

1. Eurostat. Eurostat Database. 2017. Available online: https:/ / ec.europa.eu/eurostat/data/database (accessed on 12 October 2018).

2. Schirpke, U.; Kohler, M.; Leitinger, G.; Fontana, V.; Tasser, E.; Tappeiner, U. Future impacts of changing land-use and climate on ecosystem services of mountain grassland and their resilience. Ecosyst. Serv. 2017, 26, 79-94. [CrossRef]

3. Salvador, S.; Corazzin, M.; Piasentier, E.; Bovolenta, S. Environmental assessment of small-scale dairy farms with multifunctionality in mountain areas. J. Clean. Prod. 2016, 124, 94-102. [CrossRef] 
4. Kizeková, M.; Hopkins, A.; Kanianska, R.; Makovníková, J.; Pollák, Š.; Pálka, B. Changes in the area of permanent grassland and its implications for the provision of bioenergy: Slovakia as a case study. Grass Forage Sci. 2018, 73, 218-232. [CrossRef]

5. Battaglini, L.; Bovolenta, S.; Gusmeroli, F.; Salvador, S.; Sturaro, E. Environmental sustainability of alpine livestock farms. Ital. J. Anim. Sci. 2014, 13, 431-443. [CrossRef]

6. Scarpa, R.; Notaro, S.; Louviere, J.; Raffaelli, R. Exploring scale effects of best/worst rank ordered choice data to estimate benefits of tourism in alpine grazing commons. Am. J. Agric. Econ. 2011, 93, 813-828. [CrossRef]

7. Romanzin, A.; Corazzin, M.; Piasentier, E.; Bovolenta, S. Effect of rearing system (mountain pasture vs. indoor) of Simmental cows on milk composition and Montasio cheese characteristics. J. Dairy Res. 2013, 80, 390-399. [CrossRef] [PubMed]

8. Romanzin, A.; Corazzin, M.; Favotto, S.; Piasentier, E.; Bovolenta, S. Montasio cheese liking as affected by information about cows breed and rearing system. J. Dairy Res. 2015, 82, 15-21. [CrossRef] [PubMed]

9. Kay, J.K.; Roche, J.R.; Kolver, E.S.; Thomson, N.A.; Baumgard, L.H. A comparison between feeding systems (pasture and TMR) and the effect of vitamin E supplementation on plasma and milk fatty acid profiles in dairy cows. J. Dairy Res. 2005, 72, 322-332. [CrossRef]

10. Revello Chion, A.; Tabacco, E.; Giaccone, D.; Peiretti, P.G.; Battelli, G.; Borreani, G. Variation of fatty acid and terpene profiles in mountain milk and 'Toma piemontese' cheese as affected by diet composition in different seasons. Food Chem. 2010, 121, 393-399. [CrossRef]

11. Renna, M.; Cornale, P.; Lussiana, C.; Giordano, M.; Belviso, S.; Zeppa, G.; Battaglini, L.M. Efficacy of fatty acids and terpenoids and weakness of electronic nose response as tracers of Asiago d'Allevo PDO cheese produced in different seasons. Dairy Sci. Technol. 2012, 92, 203-218. [CrossRef]

12. Dewhurst, R.J.; Shingfield, K.J.; Lee, M.R.F.; Scollan, N.D. Increasing the concentrations of beneficial polyunsaturated fatty acids in milk produced by dairy cows in high-forage systems. Anim. Feed Sci. Technol. 2006, 131, 168-206. [CrossRef]

13. Belury, M.A. Inhibition of carcinogenesis by conjugated linoleic acid: Potential mechanisms of action. J. Nutr. 2002, 132, 2995-2998. [CrossRef] [PubMed]

14. Schröder, M.; Lutz, N.L.; Tangwan, E.C.; Hajazimi, E.; Vetter, W. Phytanic acid concentrations and diastereomer ratios in milk fat during changes in the cow's feed from concentrate to hay and back. Eur. Food Res. Technol. 2012, 234, 955-962. [CrossRef]

15. De Noni, I.; Battelli, G. Terpenes and fatty acid profiles of milk fat and "Bitto" cheese as affected by transhumance of cows on different mountain pastures. Food Chem. 2008, 109, 299-309. [CrossRef] [PubMed]

16. Aprea, E.; Romanzin, A.; Corazzin, M.; Favotto, S.; Betta, E.; Gasperi, F.; Bovolenta, S. Effects of grazing cow diet on volatile compound as well as physicochemical and sensory characteristics of 12-month-ripened Montasio cheese. J. Dairy Sci. 2016, 99, 6180-6190. [CrossRef] [PubMed]

17. Ravetto Enri, S.; Renna, M.; Probo, M.; Lussiana, C.; Battaglini, L.M.; Lonati, M.; Lombardi, G. Relationships between botanical and chemical composition of forages: A multivariate approach to grasslands in the Western Italian Alps. J. Sci. Food Agric. 2017, 97, 1252-1259. [CrossRef]

18. Romanzin, A.; Corazzin, M.; Piasentier, E.; Bovolenta, S. Concentrate supplement modifies the feeding behaviour of simmental cows grazing in two high mountain pasture. Animals 2018, 8, 76. [CrossRef]

19. Bovolenta, S.; Ventura, W.; Malossini, F. Dairy cows grazing an alpine pasture: Effect of pattern of supplement allocation on herbage intake, body condition, milk yield and coagulation properties. Anim. Res. 2002, 51, 15-23. [CrossRef]

20. Bovolenta, S.; Romanzin, A.; Corazzin, M.; Spanghero, M.; Aprea, E.; Gasperi, F.; Piasentier, E. Volatile compounds and sensory properties of Montasio cheese made from the milk of Simmental cows grazing on alpine pastures. J. Dairy Sci. 2014, 97, 7373-7385. [CrossRef]

21. Berry, N.R.; Jewell, P.L.; Sutter, F.; Edwards, P.J.; Kreuzer, M. Selection, intake and excretion of nutrients by Scottish Highland suckler beef cows and calves, and Brown Swiss dairy cows in contrasting Alpine grazing systems. J. Agric. Sci. 2002, 139, 437-453. [CrossRef]

22. AOAC International. Official Methods of Analysis; AOAC International: Arlington, VA, USA, 2000.

23. Goering, H.K.; Van Soest, P.J. Forage Fiber Analyses (Apparatus, Reagents, Procedures, and Some Applications). In Agricultural Handbook No. 379; USDA Agricultural Research Service: Washington, DC, USA, 1970; pp. 387-598. 
24. IDF. Whole Milk. Determination of Milk Fat, Protein and Lactose Content. Guide for the Operation of Mid-infrared Instruments, Standard IDF 141C; International Dairy Federation: Brussels, Belgium, 2000.

25. Schutz, M.M. Genetic evaluation of somatic cell scores for United States dairy cattle. J. Dairy Sci. 1994, 77, 2113. [CrossRef]

26. Folch, J.; Less, M.; Sloane-Stanley, G.H. A simple method for the isolation and purification of total lipids from animal tissues. J. Biol. Chem. 1957, 226, 497-509.

27. Christie, W.W. Preparation of ester derivatives of fatty acids for chromatographic analysis. In Advances in Lipid Methodology-Two; Christie, W.W., Ed.; Oily Press: Dundee, Scotland, UK, 1993; pp. 69-111.

28. Povolo, M.; Pelizzola, V.; Ravera, D.; Contarini, G. Significance of the Nonvolatile Minor Compounds of the Neutral Lipid Fraction as Markers of the Origin of Dairy Products. J. Agric. Food Chem. 2009, 57, 7387-7394. [CrossRef] [PubMed]

29. Christie, W.W. Gas Chromatography and Lipids - A Practical Guide; The Oily Press: Ayr, Scotland, UK, 1989 ; p. 307.

30. Bannon, C.D.; Craske, J.D.; Hilliker, A.E. Analysis of fatty acid methyl esters with high accuracy and reliability. Fats with fatty acids containing four or more carbon atoms. J. Am. Oil Chem. Soc. 1985, 62, 1501-1507. [CrossRef]

31. Prandini, A.; Sigolo, S.; Piva, G. A comparative study of fatty acid composition and CLA concentration in commercial cheeses. J. Food Compos. Anal. 2011, 24, 55-61. [CrossRef]

32. R Core Team. R: A Language and Environment for Statistical Computing; R Foundation for Statistical Computing: Vienna, Austria, 2017; Available online: https:/ / www.R-project.org (accessed on 12 October 2018).

33. Bovolenta, S.; Spanghero, M.; Dovier, S.; Orlandi, D.; Clementel, F. Chemical composition and net energy content of alpine pasture species during the grazing season. Anim. Feed Sci. Technol. 2008, 140, 164-177. [CrossRef]

34. Coppa, M.; Chassaing, C.; Ferlay, A.; Agabriel, C.; Laurent, C.; Borreani, G.; Barcarolo, R.; Baars, T.; Kusche, D.; Harstad, O.M.; et al. Potential of milk fatty acid composition to predict diet composition and authenticate feeding systems and altitude origin of European bulk milk. J. Dairy Sci. 2015, 98, 1539-1551. [CrossRef] [PubMed]

35. Bendelja, D.; Prpić, Z.; Mikulec, N.; Ivkić, Z.; Havranek, J.; Antunac, N. Milk urea concentration in Holstein and Simmental cows. Mljekarstvo 2011, 61, 45-55.

36. Bradley, A.; Green, M. Use and interpretation of somatic cell count data in dairy cows. Practice 2005, 27, 310-315. [CrossRef]

37. Dohoo, I.R.; Leslie, K.E. Evaluation of changes in somatic cell counts as indicators of new intramammary infections. Prev. Vet. Med. 1991, 10, 225-238. [CrossRef]

38. Corazzin, M.; Piasentier, E.; Dovier, S.; Bovolenta, S. Effect of summer grazing on welfare of dairy cows reared in mountain tie-stall barns. Ital. J. Anim. Sci. 2010, 9, e59. [CrossRef]

39. Bovolenta, S.; Saccà, E.; Corazzin, M.; Gasperi, F.; Biasioli, F.; Ventura, W. Effects of stocking density and supplement level on milk production and cheese characteristics in Brown cows grazing on mountain pasture. J. Dairy Res. 2008, 75, 357-364. [CrossRef] [PubMed]

40. Collomb, M.; Sieber, R.; Bütikofer, U. CLA isomeres in milk fat from cows fed diets with high levels of unsaturated fatty acids. Lipids 2004, 39, 355-364. [CrossRef] [PubMed]

41. Kramer, J.K.G.; Hernandez, M.; Cruz-Hernandez, C.; Zhou, J. Conjugated linoleic acids and octadecenoic acids: Analyis by GC. Eur. J. Lipid Sci. Technol. 2001, 103, 594-632. [CrossRef]

42. Vlaeminck, B.; Fievez, V.; Cabrita, A.R.J.; Fonseca, A.J.M.; Dewhurst, R.J. Factors affecting odd- and branched-chain fatty acids in milk: A review. Anim. Feed Sci. Technol. 2006, 131, 389-417. [CrossRef]

43. Kilcawley, K.N.; Faulkner, H.; Clarke, H.J.; O'Sallivan, M.G.; Kerry, J.P. Factors influencing the flavor of bovine milk and cheese from grass based versus non-grass based milk production systems. Foods 2018, 7, 37. [CrossRef] [PubMed]

44. Glasser, F.; Ferlay, A.; Doreau, M.; Schmidely, P.; Sauvant, D.; Chillard, Y. Long-chain fatty acid metabolism in dairy cows: A meta-analysis of milk fatty acid yield in relation to duodenal flows and de novo synthesis. J. Dairy Sci. 2008, 91, 2771-2785. [CrossRef]

45. Khanal, R.C.; Dhiman, T.R.; Boman, R.L. Changes in fatty acid composition of milk from lactating dairy cows during transition to and from pasture. Livest. Sci. 2008, 114, 164-175. [CrossRef] 
46. Bovolenta, S.; Corazzin, M.; Saccà, E.; Gasperi, F.; Biasioli, F.; Ventura, W. Performance and cheese quality of Brown cows grazing on mountain pasture fed two different levels of supplementation. Livest. Sci. 2009, 124, 58-65. [CrossRef]

47. Rego, O.A.; Cabrita, A.R.J.; Rosa, H.J.D.; Alves, S.P.; Duarte, V.; Fonseca, A.J.M.; Vouzela, C.F.M.; Pires, F.R.; Bessa, R.J.B. Changes in milk production and milk fatty acid composition of cows switched from pasture to a total mixed ration diet and back to pasture. Ital. J. Anim. Sci. 2016, 15, 76-86. [CrossRef]

48. Dewanckele, L.; Vlaeminck, B.; Hernandez-Sanabria, E.; Ruiz-González, A.; Debruyne, S.; Jeyanathan, J.; Fievez, V. Rumen Biohydrogenation and Microbial Community Changes Upon Early Life Supplementation of 22:6n-3 Enriched Microalgae to Goats. Front. Microbiol. 2018, 9, 573. [CrossRef] [PubMed]

49. Marín, M.P.; Meléndez, P.G.; Aranda, P.; Ríos, C. Conjugated linoleic acid content and fatty acids profile of milk from grazing dairy cows in southern Chile fed varying amounts of concentrate. J. Appl. Anim. Res. 2018, 46, 150-154.

50. Agabriel, J. Alimentation des Bovins, Ovins et Caprins; Quae: Versailles, France, 2010.

51. Khiosa-ard, R.; Kreuzer, M.; Leiber, F. Apparent recovery of C18 polyunsaturated fatty acids from feed in cow milk: A meta-analysis of the importance of dietary fatty acids and feeding regimes in diets without fat supplementation. J. Dairy Sci. 2015, 98, 6399-6414. [CrossRef] [PubMed]

52. Falchero, L.; Coppa, M.; Lonati, M.; Odoardi, M.; Lombardi, G. Milk fatty acid profile in relation to botanical and chemical composition of Alpine pasture. In Proceedings of the 15th meeting of the FAO-CIHEAM Mountain Pasture Network, Les Diablerets, Switzerland, 7-8 October 2009; Agroscope: Zurich, Switzerland, 2009; pp. 165-166.

53. Gorlier, A.; Lonati, M.; Renna, M.; Lussiana, C.; Lombardi, G.; Battaglini, L.M. Changes in pasture and cow milk compositions during a summer transhumance in the western Italian Alps. J. Appl. Bot. Food Qual. 2012, 85, 216-223.

54. Collomb, M.; Bütikofer, U.; Sieber, R.; Jeangros, B.; Bosset, J.O. Correlation between fatty acids in cows' milk fat produced in the lowlands, mountains and highlands of Switzerland and botanical composition of the fodder. Int. Dairy J. 2002, 12, 661-666. [CrossRef]

55. Jayanegara, A.; Kreuzer, M.; Leiber, F. Ruminal disappearance of polyunsaturated fatty acids and appearance of biohydrogenation products when incubating linseed oil with alpine forage plant species in vitro. Livest. Sci. 2012, 147, 104-112. [CrossRef]

56. Kliem, K.E.; Thomson, A.L.; Crompton, L.A.; Givens, D.I. Effect of selected plant species within biodiverse pasture on in vitro fatty acid biohydrogenation and tissue fatty acid composition of lamb. Animal 2018, 22, 2415-2423. [CrossRef]

57. Vetter, W.; Schröder, M. Concentrations of phytanic acid and pristanic acid are higher in organic than in conventional dairy products from the German market. Food Chem. 2010, 119, 746-752. [CrossRef]

58. Che, B.N.; Kristensen, T.; Nebel, C.; Dalsgaard, T.K.; Hellgren, L.I.; Young, J.F.; Larsen, M.K. Content and distribution of phytanic acid diastereomers in organic milk as affected by feed composition. J. Agric. Food Chem. 2013, 61, 225-230. [CrossRef]

59. EFSA. Dietary reference values for nutrients: Summary report. EFSA Support. Publ. 2017, 14, e15121.

60. Ohlsson, L. Dairy products and plasma cholesterol levels. Food Nutr. Res. 2010, 54, 5124. [CrossRef] [PubMed]

61. Coppa, M.; Ferlay, A.; Monsalier, F.; Verdier-Metz, L.; Pradel, P.; Didierne, R.; Farruggia, A.; Montel, M.C.; Martin, B. Milk fatty acid composition and cheese texture and appearance from cows fed hay or different grazing systems on upland pastures. J. Dairy Sci. 2011, 94, 1132-1145. [CrossRef] [PubMed]

62. McSweeney, P.L.H. Biochemistry of cheese ripening. Int. J. Dairy Technol. 2004, 57, 127-144. [CrossRef]

63. Türkoğlu, H. Free fatty acid composition and sensory characteristics of Örgü cheese. Sci. Res. Essays 2011, 6, 1555-1560. 
64. Palin, M.F.; Côrtes, C.; Benchaar, C.; Lacasse, P.; Petit, H.V. mRNA expression of lipogenic enzymes in mammary tissue and fatty acid profile in milk of dairy cows fed flax hulls and infused with flax oil in the abomasum. Br. J. Nutr. 2014, 111, 1011-1020. [CrossRef] [PubMed]

65. Corazzin, M.; Bovolenta, S.; Saccà, E.; Bianchi, G.; Piasentier, E. Effect of linseed addition on the expression of some lipid metabolism genes in the adipose tissue of young Italian Simmental and Holstein bulls. J. Anim. Sci. 2013, 91, 405-412. [CrossRef] [PubMed] 